University of Wollongong

Research Online

Faculty of Engineering and Information

Faculty of Engineering and Information

Sciences - Papers: Part A

Sciences

$1-1-2016$

Reduction of quartz to silicon monoxide by methane-hydrogen mixtures

Xiang Li

University of Wollongong, x|450@uowmail.edu.au

Guangqing Zhang

University of Wollongong, gzhang@uow.edu.au

Ragnar Tronstad

Elkem AS, ragnar.tronstad@elkem.no

Oleg Ostrovski

University of New South Wales, o.ostrovski@unsw.edu.au

Follow this and additional works at: https://ro.uow.edu.au/eispapers

Part of the Engineering Commons, and the Science and Technology Studies Commons

Research Online is the open access institutional repository for the University of Wollongong. For further information contact the UOW Library: research-pubs@uow.edu.au 


\title{
Reduction of quartz to silicon monoxide by methane-hydrogen mixtures
}

\author{
Abstract \\ The reduction of quartz was studied isothermally in a fluidized bed reactor using continuously flowing \\ methane-hydrogen gas mixture in the temperature range from $1623 \mathrm{~K}$ to $1773 \mathrm{~K}\left(1350{ }^{\circ} \mathrm{C}\right.$ to $\left.1500{ }^{\circ} \mathrm{C}\right)$. The \\ $\mathrm{CO}$ content in the off-gas was measured online using an infrared gas analyzer. The main phases of the \\ reduced samples identified by XRD analysis were quartz and cristobalite. Significant weight loss in the \\ reduction process indicated that the reduction products were $\mathrm{SiO}$ and $\mathrm{CO}$. Reduction of $\mathrm{SiO} 2$ to $\mathrm{SiO}$ by \\ methane starts with adsorption and dissociation of $\mathrm{CH} 4$ on the silica surface. The high carbon activity in \\ the $\mathrm{CH} 4-\mathrm{H} 2$ gas mixture provided a strongly reducing condition. At $1623 \mathrm{~K}\left(1350^{\circ} \mathrm{C}\right)$, the reduction was \\ very slow. The rate and extent of reduction increased with the increasing temperature to $1723 \mathrm{~K}$ ( 1450 \\ $\left.{ }^{\circ} \mathrm{C}\right)$. A further increase in temperature to $1773 \mathrm{~K}\left(1500^{\circ} \mathrm{C}\right)$ resulted in a decrease in the rate and extent of \\ reduction. An increase in the gas flow rate from 0.4 to $0.8 \mathrm{NL} / \mathrm{min}$ and an increase in the methane content \\ in the $\mathrm{CH} 4-\mathrm{H} 2$ gas mixture from 0 to $5 \mathrm{vol}$ pct facilitated the reduction. Methane content in the gas \\ mixture should be maintained at less than 5 vol pct in order to suppress methane cracking.

\section{Keywords} \\ mixtures, quartz, monoxide, reduction, methane, hydrogen, silicon \\ Disciplines \\ Engineering | Science and Technology Studies

\section{Publication Details} \\ Li, X., Zhang, G., Tronstad, R. \& Ostrovski, O. (2016). Reduction of quartz to silicon monoxide by methane- \\ hydrogen mixtures. Metallurgical and Materials Transactions B: Process Metallurgy and Materials \\ Processing Science, 478 2197-2204.
}




\section{Reduction of Quartz to Silicon Monoxide by Methane-hydrogen Mixtures}

2

$3{ }^{1}$ School of Mechanical, Materials and Mechatronic Engineering, University of Wollongong,

$4 \quad$ Wollongong, NSW 2522, Australia

$5 \quad$ 2Elkem AS, Drammensveien 169, Skøyen, P.O Box 334, 0213 Oslo, Norway

$6{ }^{3}$ School of Materials Science and Engineering, University of New South Wales, Sydney,

$7 \quad$ NSW 2052, Australia

8

\section{Abstract}

\author{
Xiang Li $^{1 *}$, Guangqing Zhang ${ }^{1}$, Ragnar Tronstad ${ }^{2}$, Oleg Ostrovski ${ }^{3}$
}

The reduction of quartz was studied isothermally in a fluidized bed reactor with continuously flowing methane-hydrogen gas mixture in the temperature range of $1623 \mathrm{~K}\left(1350{ }^{\circ} \mathrm{C}\right)$ to $1773 \mathrm{~K}\left(1500{ }^{\circ} \mathrm{C}\right)$. The $\mathrm{CO}$ content in the off-gas was measured online using an infrared gas analyzer. The main phases of the reduced samples identified by XRD analysis were quartz and cristobalite. Significant weight loss in the reduction process indicated that the reduction products were $\mathrm{SiO}$ and $\mathrm{CO}$. Reduction of $\mathrm{SiO}_{2}$ to $\mathrm{SiO}$ by methane starts with adsorption and dissociation of $\mathrm{CH}_{4}$ on the silica surface. The high carbon activity in the $\mathrm{CH}_{4}-\mathrm{H}_{2}$ gas mixture provided a strongly reducing condition. At $1623 \mathrm{~K}\left(1350^{\circ} \mathrm{C}\right)$, the reduction was very slow. The rate and extent of reduction increased with increasing temperature to $1723 \mathrm{~K}\left(1450{ }^{\circ} \mathrm{C}\right)$. A further increase in temperature to $1773 \mathrm{~K}\left(1500^{\circ} \mathrm{C}\right)$ resulted in a decrease in the rate and

\footnotetext{
* Author to whom correspondence should be addressed. e-mail: x1450@uowmail.edu.au; Tel.: +61 024211 5293; fax: +61 0242213112 .
} 
1 extent of reduction. An increase in the gas flow rate from 0.4 to $0.8 \mathrm{NL} / \mathrm{min}$ and increase in

2 the methane content in the $\mathrm{CH}_{4}-\mathrm{H}_{2}$ gas mixture from 0 to 5 vol pct favored the reduction.

3 Methane content in the gas mixture should be maintained below 5 vol pct in order to suppress

4 methane cracking.

\section{$5 \quad$ I. Introduction}

6 Metallurgical silicon and ferrosilicon alloys are produced in submerged electric arc furnaces

7 by carbothermal reduction of silicon bearing oxides (typically quartz) with carbonaceous

8 materials. Coal, coke, charcoal and woodchips are commonly used as reductants in these

9 processes [1]. Carbothermal reduction requires high temperatures and is energy intensive.

10 The contents of trace elements in both quartz and reductants determine the purity of the

11 produced silicon [2]. SiC is also produced by the carbothermal reduction of quartz.

Silicon monoxide $(\mathrm{SiO})$ vapor is one of the major intermediate species in the production of

$\mathrm{SiC}$ and metallurgical silicon $[3,4] . \mathrm{SiO}_{2}$ is reduced by carbon to $\mathrm{SiO}$ by the following reaction:

$$
\mathrm{SiO}_{2}+\mathrm{C}=\mathrm{SiO}(\mathrm{g})+\mathrm{CO}(\mathrm{g})
$$

$\mathrm{SiO}$ further reacts with carbon to form $\mathrm{SiC}$ :

$$
\mathrm{SiO}(\mathrm{g})+2 \mathrm{C}=\mathrm{SiC}+\mathrm{CO}(\mathrm{g})
$$


2 The primary reaction for production of $\mathrm{Si}$ is the following:

$$
\mathrm{SiC}+\mathrm{SiO}(\mathrm{g})=2 \mathrm{Si}(\mathrm{l})+\mathrm{CO}(\mathrm{g})
$$

6 Methane has the advantage of high purity over conventional carbonaceous reductants such as

7 coal or coke which always contain impurities [5-7]. The gas-phase reaction between $\mathrm{SiO}$ and

8 methane with or without a catalyst has been used for synthesis of SiC whiskers [8-12].

9 However, no reports were found in the literature on the direct reduction of $\mathrm{SiO}_{2}$ to $\mathrm{SiO}$ by the methane-containing gas. The purpose of the present study is to investigate the possibility of reduction of quartz to $\mathrm{SiO}$ via the gas-solid reaction by methane-hydrogen gas mixture, as described by Reaction [4]. Natural gas contains low harmful impurities of solar silicon, and provides high carbon activity for the reduction of quartz, which makes it an attractive reductant over conventional solid carbon.

$$
\mathrm{SiO}_{2}+\mathrm{CH}_{4}(\mathrm{~g})=\mathrm{SiO}(\mathrm{g})+\mathrm{CO}(\mathrm{g})+2 \mathrm{H}_{2}(\mathrm{~g})
$$

Above $1729 \mathrm{~K}\left(1456{ }^{\circ} \mathrm{C}\right)$, Reaction [4] has a negative Gibbs free energy change under standard conditions $\left(\Delta \mathrm{G}^{\circ}\right)$; at $1873 \mathrm{~K}\left(1600^{\circ} \mathrm{C}\right), \Delta \mathrm{G}^{\circ}=-63.2 \mathrm{~kJ}$ (calculated using HSC Chemistry 6.1). However, methane is unstable at temperatures above $823 \mathrm{~K}\left(550{ }^{\circ} \mathrm{C}\right)$; it cracks with deposition of solid carbon (Reaction [5]) at temperatures above $1273 \mathrm{~K}\left(1000{ }^{\circ} \mathrm{C}\right)$ [13]. Solid carbon deposits on the sample surface, hindering further progress of the reduction 
by blocking the quartz particle surface.

$$
\mathrm{CH}_{4}(\mathrm{~g})=\mathrm{C}+2 \mathrm{H}_{2}(\mathrm{~g})
$$

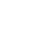

Therefore, reduction of metal oxides by the methane-containing gas should be conducted under conditions at which cracking of methane is limited.

This study examines the effects of temperature, gas composition and gas flow rate on the reduction of quartz in the fluidized bed reactor by the $\mathrm{CH}_{4}-\mathrm{H}_{2}$ gas mixture with a low $\mathrm{CH}_{4} / \mathrm{H}_{2}$ ratio to suppress methane cracking. Reduction of quartz to $\mathrm{SiO}$ can be of commercial interest; however, scaling up and further study of this process are needed to find feasibility of the industrial reduction of quartz by the methane-containing gas.

\section{Experimental}

4 A fluidized bed reactor was adopted to mitigate the effect of carbon deposition on the surface of quartz particles. Quartz powder with a particle size of $100-140 \mu \mathrm{m}$ was obtained by crushing and grinding quartz lumps (supplied by Elkem AS, Norway) by an agate mill and sieving to the size range. The impurity contents in quartz lumps were provided by the supplier, as shown in Table I. The gases $\left(\mathrm{CH}_{4}, \mathrm{Ar}\right.$ and $\left.\mathrm{H}_{2}\right)$ used in the investigation were of $99.999 \mathrm{pct}$ purity, supplied by Coregas Pty Ltd, Australia. 
1 The fluidization of quartz particles was first verified using a cold model of the fluidization

2 reactor made of Perspex material. It consisted of two zones, a fluidization zone (inner

3 diameter $20 \mathrm{~mm}$ ) in which a fluidized bed was formed, and a settling zone (inner diameter 40

$4 \mathrm{~mm}$ ). The settling zone had an enlarged intersection and therefore a lower gas flow rate,

5 which allowed the quartz particles brought into the settling zone by ascending gas stream to

6 settle and return to the fluidized bed. A connector with a filter was installed at the bottom of

7 the fluidized bed which played a role of a gas distributor. Fluidisation of quartz powder with

8 particle size in the ranges of 53-100 $\mu \mathrm{m}, 100-140 \mu \mathrm{m}$ and $140-200 \mu \mathrm{m}$ in the cold model

9 was examined using nitrogen with different flow rates. The change of quartz bed was recorded by a video camera (D5100, Nikon Corporation, Tokyo, Japan).

The schematic of the fluidized bed high-temperature reactor for the reduction experiments is presented in Figure 1. The reactor was made from graphite; it was installed within an alumina tube of $50 \mathrm{~mm}$ ID. The inner diameter of the fluidization zone was $20 \mathrm{~mm}$, and settling zone was $40 \mathrm{~mm}$. A type B thermocouple protected by an alumina sheath was inserted into the fluidization zone to measure the temperature before introducing quartz powder, then it was removed from the fluidization zone to avoid disturbing the fluidization of quartz powder during reaction. An alumina tube was inserted into the settling zone which was used to feed quartz samples into the reactor.

In an experiment, the reactor system was first assembled, purged with argon, and heated to the experimental temperature. Then the methane-hydrogen gas mixture was introduced, and 2 
$1 \mathrm{~g}$ of quartz was added into the fluidizing zone of the reactor via the feeding tube. After

2 reduction for certain time, the furnace was cooled, the reactor was disassembled, and the

3 sample taken for characterization. Argon was introduced between the graphite reactor and

4 outside alumina tube to make sure that all of the gaseous reacting products were purged out

5 of the reaction system. The total inlet gas flow rate (reducing and purging) was maintained at

$6 \quad 1.00 \mathrm{NL} / \mathrm{min}$.

(Figure 1)

8 The reaction between methane and quartz was also studied using a fused quartz sphere with 9 diameter of $15.90 \mathrm{~mm}$ (99.99 pet $\mathrm{SiO}_{2}$, provided by Guolun Quartz Products Co. Ltd, China) hung in the methane-hydrogen gas mixture. The reaction system was setup in a graphite tube furnace (Model 1000-2560-FP20, GT Advanced Technologies, Santa Rosa, U.S.A.). A quartz sphere was suspended by a tungsten wire with $0.5 \mathrm{~mm}$ diameter from the top into the hot zone of a reactor tube (high-purity graphite) with $26 \mathrm{~mm}$ internal diameter. A methanehydrogen gas mixture flowed downward through the tube. The furnace was heated to the targeted temperature at $20 \mathrm{~K} / \mathrm{min}$ under argon atmosphere. Then the gas was switched to a methane-hydrogen mixture. Reaction was stopped after certain time by lowering the temperature at $20 \mathrm{~K} / \mathrm{min}$. After reaction, the sphere was weighed and analyzed.

In both reduction experiments, the off gas composition was continuously monitored and recorded every 5 seconds by an infrared $\mathrm{CO} / \mathrm{CO}_{2} / \mathrm{CH}_{4}$ analyzer (Advanced optima $\mathrm{AO} 2020$, ABB, Ladenburg, Germany) connected with a computer. 
1 The original quartz particles and reduced samples were analyzed by X-ray diffraction (XRD,

2 MMA, GBC Scientific Equipment, Braeside, Australia). The fine powder of a sample was

3 scanned at a speed of $0.02 \%$ and step size $0.02^{\circ}$ with $\mathrm{CuK}$ radiation generated at $35 \mathrm{kV}$ and $4 \quad 28.6 \mathrm{~mA}$.

6 SEM images were recorded by field-emission scanning electron microscopy (FESEM, 7 JSM-6000, JEOL, Tokyo, Japan) operated at $15 \mathrm{kV}$. The chemical composition of the samples 8 was analysed by an energy-dispersive X-ray spectrometer (EDS). The samples were coated 9 with gold to enhance conductivity in SEM/EDS analyses.

11 The extent of reduction was defined as a fraction of oxygen in quartz removed in the course 12 of reduction, in the form of $\mathrm{CO}$ and $\mathrm{SiO}$ according to Reaction [4]. Using the $\mathrm{CO}$ concentration in the off gas, the extent of reduction (X, pct) was calculated using Eq. [6].

$$
X=\frac{2}{n_{O-i}} \int_{0}^{t} \frac{F}{22.4} C_{V-C O} d t
$$

17 where $\mathrm{C}_{\mathrm{V}-\mathrm{CO}}$ is the concentration of $\mathrm{CO}$, vol pct; $\mathrm{n}_{\mathrm{O}-\mathrm{i}}$ is the initial content of oxygen in 18 quartz, mol, $\mathrm{F}$ is the inlet gas flow rate, $\mathrm{NL} / \mathrm{min}$, $\mathrm{t}$ is reaction time, $\mathrm{min}$.

\section{Experimental Results}


were estimated using the following correlations [14]:

2

3

4

$5 \quad$ where $d_{p}=$ diameter of quartz particles, $\mathrm{cm}$;

6

(1)

(1)

$$
\begin{aligned}
& U_{m f}=\left[d_{p}^{2} g\left(\rho_{p}-\rho_{g}\right)\right] /(1650 \mu) \\
& U_{t}=\left[d_{p}^{2} g\left(\rho_{p}-\rho_{g}\right)\right] /(18 \mu)
\end{aligned}
$$

The fluidization of quartz particles of different particle size ranges was first verified using a cold model fluidization reactor. The $\mathrm{N}_{2}$ flow rate was changed from $0.1-1.2 \mathrm{NL} / \mathrm{min}$. Table II compares the measured $\mathrm{U}_{\mathrm{mf}}$ values with calculated using Eq. [7] and gas properties at $293 \mathrm{~K}$ $\left(25^{\circ} \mathrm{C}\right)$. Calculated $\mathrm{U}_{\mathrm{t}}$ using Eq. [8] is also listed in Table II.

\section{(Table II)}

In the case of quartz particles in the size range $53-100 \mu \mathrm{m}$, fluidization by gas with tested flow rate $0.1-1.2 \mathrm{NL} / \mathrm{min}$ was not observed; channeling took place in the bed. The minimum fluidization velocity for particles $100-140 \mu \mathrm{m}$ was close to that calculated by Eq. [7]. In the case of 140-200 $\mu \mathrm{m}$ quartz particles, the measured minimum fluidization velocity was significantly smaller than the calculated value. The terminal gas velocity was not reached in both cases in the tested range of gas flow rate. 
1 The calculated parameters of fluidization of quartz particles with size $100-140 \mu \mathrm{m}$ by pure 2 hydrogen at temperatures $1623 \mathrm{~K}\left(1350^{\circ} \mathrm{C}\right)$ to $1773 \mathrm{~K}\left(1500{ }^{\circ} \mathrm{C}\right)$ are listed in Table III.

3 Calculated data indicate that fluidization of quartz particles can be operated in a wide range 4 of $\mathrm{H}_{2}$ gas flow rate $(0.036-1.494 \mathrm{NL} / \mathrm{min})$.

5

6

7 Table IV summarises experimental conditions and weights of samples before and after

8 reduction. The effect of temperature was studied in the temperature range of $1623 \mathrm{~K}\left(1350{ }^{\circ} \mathrm{C}\right)$

\section{(Table III)}

\section{B. Reduction of quartz to SiO in the fluidized bed reactor} to $1773 \mathrm{~K}\left(1500{ }^{\circ} \mathrm{C}\right)$ at constant fluidizing gas flow rate of $0.8 \mathrm{NL} / \mathrm{min}$ and gas composition of 5 vol pct $\mathrm{CH}_{4}-95 \mathrm{vol}$ pct $\mathrm{H}_{2}$. The reduction extent calculated from the off gas composition was always slightly higher that the extent of reduction found from the weight loss. This discrepancy can be attributed to the loss of some fine $\mathrm{SiO}_{2}$ particles in the fluidized bed generated from the friction/collision among quartz particles. These fine particles were easily carried out of the fluidized bed by the gas stream. It was noticed that the deviation was greater with higher fluidizing gas flow rate and higher temperature. Therefore, the reduction extent calculated from the off gas composition was more reliable in this investigation.

The change of CO concentration in the off gas $v s$ time at different temperatures is shown in Figure 2. Figure 3 presents the XRD spectra of the samples reduced at different temperatures for $120 \mathrm{~min}$.

(Table IV) 
2 At $1623 \mathrm{~K}\left(1350{ }^{\circ} \mathrm{C}\right)$, the $\mathrm{CO}$ concentration reached 0.078 vol pct in about 5 min after

3

4

5

6

7 introducing quartz powder, then declined slowly to about 0.024 vol pet at $40 \mathrm{~min}$. After 120 min of reaction, the extent of reduction calculated from the CO concentration in the off-gas was only $4.4 \mathrm{pct}$; XRD analysis of the sample after reaction detected only quartz. The reduction at this temperature was very slow. Increasing temperature to $1673 \mathrm{~K}\left(1400{ }^{\circ} \mathrm{C}\right)$ resulted in a significant increase of the reduction rate; the $\mathrm{CO}$ concentration in the off gas reached $0.37 \mathrm{vol}$ pct after $3.2 \mathrm{~min}$ reaction. After $120 \mathrm{~min}$ reduction, the extent of reduction was 25.0 pct. Further increasing temperature to $1723 \mathrm{~K}\left(1450{ }^{\circ} \mathrm{C}\right)$ accelerated the reaction rate, brought about the extent of reduction to $32.0 \mathrm{pct}$ in $120 \mathrm{~min}$. In addition to the quartz peaks, cristobalite peaks were detected in the XRD spectrum of the reduced sample as a result of the transformation of quartz to cristobalite at high temperatures [15]. Stronger cristobalite peaks were observed in the XRD spectrum of the sample reduced at $1773 \mathrm{~K}\left(1500{ }^{\circ} \mathrm{C}\right)$. The CO concentration raised quickly to 1.14 vol pet after quartz powder was introduced to the reaction zone, however, it droped sharply to less than 0.19 vol pct after 10 min reaction.

No $\mathrm{SiC}$ was identified by the XRD analysis of the samples reduced at different temperatures, although further reaction of $\mathrm{SiO}$ with $\mathrm{CH}_{4}$ via Reaction [9] is thermodynamically feasible. This means that either no $\mathrm{SiC}$ was formed on the surface of quartz particles or the $\mathrm{SiC}$ yield was too low to be detected by XRD. Thermodynamic calculation using HSC Chemistry 6.1 showed that Reaction [9] is practically irreversible with the equilibrium constant in the order of $10^{7}$ to $10^{8}$ in the considered temperature range. The fact that Reaction [9] did not occur in 
1 the fluidized bed is attributed to the kinetic barrier in the SiC nucleation in the bed.

2

3

4

5 The effect of fluidizing gas flow rate on the reduction of quartz was examined at $1723 \mathrm{~K}$

$6 \quad\left(1450{ }^{\circ} \mathrm{C}\right)$ in the range 0.4 to $0.8 \mathrm{NL} / \mathrm{min}$ with a constant methane concentration of 5 vol pct.

$$
\mathrm{SiO}(\mathrm{g})+2 \mathrm{CH}_{4}(\mathrm{~g})=\mathrm{SiC}+\mathrm{CO}(\mathrm{g})+4 \mathrm{H}_{2}(\mathrm{~g})
$$

Total gas flow through the gas analyzer (fluidizing and purging) was kept constant at 1.0

$\mathrm{NL} / \mathrm{min}$. Figure 4 depicts the change of CO concentration in the off gas $v s$ time for different gas flow rates. At a low gas flow rate of $0.4 \mathrm{NL} / \mathrm{min}, \mathrm{CO}$ concentration reached 0.27 vol pct nearly instantly when the quartz powder was introduced into the reactor. The peak CO concentration increased nearly proportionally with increasing gas flow rate.

\section{(Figure 4)}

The effect of methane content in the gas mixture on the reduction of quartz was examined at 2, 5 and 10 vol pct, keeping fluidizing gas flow rate at $0.8 \mathrm{NL} / \mathrm{min}$ and temperature at $1723 \mathrm{~K}$ $\left(1450{ }^{\circ} \mathrm{C}\right)$. The change of $\mathrm{CO}$ concentration $v s$ time in experiments with different methane contents is shown in Figure 5. The CO peak concentration and extent of reduction increased with increasing methane content in the gas mixture from 2 to 5 vol pct. In the experiment with 10 vol pct of methane, the reduction rate was much faster at the beginning of the reaction, however it decreased dramatically, and the final extent of reduction was low (4.6 pct after $120 \mathrm{~min})$. The sample after reduction became black, indicating deposition of solid carbon on the particle surface due to excessive methane decomposition (Reaction [5]) which 
retarded the reduction.

\section{Discussion}

4 Reduction of solid silica by gaseous hydrogen-methane mixture is a typical gas-solid reaction

5 in which a gaseous reductant diffuses to the gas-solid phase boundary where reactions take

6 place, and the gaseous products diffuse back into the bulk gas. The rate of the whole process

7 is determined by the slowest step in a series of reactions and mass transfer steps.

9 Quartz reduction by $\mathrm{CH}_{4}-\mathrm{H}_{2}$ gas was strongly affected by the reduction temperature (Figure 2). Applying Arrhenius law to the peak rate of reduction at different temperatures, apparent activation energy of $408 \mathrm{~kJ} / \mathrm{mol}$ was obtained, with a correlation coefficient of 0.94 between the $\mathrm{CO}$ peak concentration (which characterises the rate of reduction) and reciprocal of absolute temperature (Figure 6). Such high activation energy is expected for processes with intrinsic reaction kinetics. According to Figure 4, the reaction rate increased with gas flow rate. The increase of the reaction rate with flow rate is an indication of the effect of the external mass transfer. However, the gas flow rate also affected the thermal cracking of methane in the gas phase $[16,17]$; the degree of methane cracking increased with increasing residence time which decreased with increasing gas flow rate. The actual methane concentration in the fluidized bed at the gas flow rates 0.4 and $0.6 \mathrm{NL} / \mathrm{min}$ was higher than that at $0.8 \mathrm{NL} / \mathrm{min}$, at which the optimum methane content in the gas stream was established within the range of 5 vol pct (Figure 5). Therefore, increase in the gas flow rate decreased the 
actual methane content in the reactor with a positive effect on the reaction rate.

3 Reduction of $\mathrm{SiO}_{2}$ to $\mathrm{SiO}$ by methane proceeds through Reaction (4). The reaction starts with

4 adsorption and dissociation of $\mathrm{CH}_{4}$ on the silica surface $\mathrm{CH}_{4} \rightarrow \ldots \rightarrow \mathrm{C}_{\mathrm{ad}}+2 \mathrm{H}_{2}$. Carbon

5 activity in the system is in the range of 15.2-27.1 [18]. Adsorbed highly active carbon forms

6 strong bonds with oxygen atom and then forms $\mathrm{CO}$ which is released from the surface to the

7 gas phase. The removal of an oxygen atom from the silica surface increases the energy states

8 of nearby oxygen and silicon; a volatile $\mathrm{SiO}$ molecule is formed and released from the 9 surface.

10 However, the use of pure methane or $\mathrm{CH}_{4}-\mathrm{H}_{2}$ gas mixture with high methane concentration leads to cracking of methane and deposition of carbon black which blocks the reaction sites on the surface of quartz. Moreover, deposition of solid carbon decreases thermodynamic activity of carbon in the system. The major role of hydrogen in the $\mathrm{CH}_{4}-\mathrm{H}_{2}$ gas mixture is to control carbon activity in the system avoiding excessive methane cracking. Hydrogen can directly reduce silica to $\mathrm{SiO}$ by Reaction [10], which proceeds through adsorption of $\mathrm{H}$ atoms on the silica surface $[19,20]$. Low partial pressure of $\mathrm{H}_{2} \mathrm{O}$ needed for Reaction [10] to occur is maintained by Reaction [11]. A combination of these two reactions gives Reaction [4], therefore thermodynamics of the combination of Reactions [10] and [11] is equivalent to the thermodynamics of Reaction [4]. However, Reaction [4] proceeds under strongly non-equilibrium conditions; the use of active carbon secures reduction of $\mathrm{SiO}_{2}$ to $\mathrm{SiO}$. 


$$
\mathrm{SiO}_{2}+\mathrm{H}_{2}(\mathrm{~g})=\mathrm{H}_{2} \mathrm{O}(\mathrm{g})+\mathrm{SiO}(\mathrm{g})
$$

$$
\mathrm{CH}_{4}(\mathrm{~g})+\mathrm{H}_{2} \mathrm{O}(\mathrm{g})=\mathrm{CO}(\mathrm{g})+3 \mathrm{H}_{2}(\mathrm{~g})
$$

5 Following Reaction [4], methane diffuses to the reaction interface while $\mathrm{SiO}, \mathrm{CO}$ and $\mathrm{H}_{2}$ 6 diffuse away from the reaction interface. Mass transfer of $\mathrm{SiO}$ and $\mathrm{CO}$ in the gas phase can

7 contribute to the reaction rate control. The concentration of hydrogen in the gas phase is quite

8 high; its diffusion is not expected to have an effect on the rate of reaction.

9 The low degree of conversion of $\mathrm{SiO}_{2}$ to $\mathrm{SiO}$ can be explained by the low specific surface 10 area of quartz sand (estimated value $0.008-0.011 \mathrm{~m}^{2} / \mathrm{g}$ ). Decrease in the rate of reduction with reaction time and relatively low extent of reduction was related to the deposition of carbon black as described above. Moreover, the change in the rate controlling mechanisms in the course of reduction cannot be excluded.

The reduction of quartz was studied further using quartz spheres, which were suspended by a tungsten wire in the $\mathrm{CH}_{4}-\mathrm{H}_{2}$ gas mixture. The methane content in the gas mixture was maintained at $0.5 \mathrm{vol}$ pct to minimize the effect of the methane cracking. The change of $\mathrm{CO}$ concentration $v s$ time in the off gas is presented in Figure 7. The CO concentration decreased rapidly in the first $40 \mathrm{~min}$. With the increase of the reaction temperature, the reaction rate increased, and the $\mathrm{CO}$ concentration curve became more fluctuant. 
1 Applying Arrhenius law to the apparent reaction rate constant obtained from Figure 7,

2 apparent activation energy was obtained to be $207 \mathrm{~kJ} / \mathrm{mol}$. This value is only about 50 pct of

3 the value obtained from experimental data using the fluidized bed reactor, indicating that the

4 reaction rate was affected by the external diffusion of gas species from the reaction interface.

5 Continuous movement of the quartz particles in the fluidized bed reactor generated a stirring

6 effect; the effect of external diffusion on the reaction rate in the fluidized bed reactor was

7 relatively small.

8

9 The surfaces of quartz spheres after reduction at $1723 \mathrm{~K}\left(1450{ }^{\circ} \mathrm{C}\right)$ and $1773 \mathrm{~K}\left(1500{ }^{\circ} \mathrm{C}\right)$ were examined by SEM. The SEM images of the quartz spheres presented in Figure 8 show cracks on the surfaces due to phase transformation of quartz into cristobalite which created stress within the spheres. Surface cracking exposed fresh surface of quartz to the reducing gas causing increase in the reduction rate, which explains fluctuations in the concentration of $\mathrm{CO}$ evolved in the reduction process.

\section{(Figure 8)}

Figure 9 presents the surfaces of the quartz spheres after reaction at different temperatures at a higher magnification. The surface of quartz was smooth before reaction; it was eroded and became porous after reaction at $1623 \mathrm{~K}\left(1350^{\circ} \mathrm{C}\right)$ (Figure 9a). Development of the porous structure increased surface area. In the reduction at $1723 \mathrm{~K}\left(1450{ }^{\circ} \mathrm{C}\right)$ and $1773 \mathrm{~K}\left(1500{ }^{\circ} \mathrm{C}\right)$, a small amount of $\mathrm{SiC}$ particles was observed on the surfaces of quartz spheres (Figures $9 \mathrm{~b}$ and 9c), which was confirmed by the EDS analysis. SiC was formed by the reaction of 
1 deposited carbon with $\mathrm{SiO}$. Amount of observed $\mathrm{SiC}$ particles in the sphere reduced at 1723

$2 \mathrm{~K}\left(1450{ }^{\circ} \mathrm{C}\right)$ was higher than in the sphere reacted at $1673 \mathrm{~K}\left(1400^{\circ} \mathrm{C}\right)$.

3

4 The surface of the sphere after reaction at $1773 \mathrm{~K}\left(1500^{\circ} \mathrm{C}\right)$ was covered by $\mathrm{SiC}$ whiskers

5 (Figure 9d). As studied previously [8-11], SiC whiskers in the reduction of quartz containing 6 iron impurities were formed by the reaction of $\mathrm{CH}_{4}$ and $\mathrm{SiO}$ under catalytic effect of iron or 7 other transition metal elements, i.e. VLS (vapor-liquid-solid) mechanism. However, no 8 catalyst globules were observed at the tip of $\mathrm{SiC}$ whiskers in this study, indicating that they 9 were formed via VS (vapor-solid) mechanism occurred by gas-gas ( $\left.\mathrm{SiO}-\mathrm{CH}_{4}\right)$ Reaction [9]. $\mathrm{SiC}$ whiskers were not found in the samples reduced at lower temperatures due to low $\mathrm{SiO}$ vapor pressure [12].

\section{Conclusions}

The reduction of quartz by methane-containing gas was studied in a laboratory fluidized bed reactor. A cold model was made which established the fluidization conditions of quartz powder. Direct reduction of quartz by $\mathrm{CH}_{4}-\mathrm{H}_{2}$ mixture is feasible, but in the temperature range of $1623 \mathrm{~K}\left(1350{ }^{\circ} \mathrm{C}\right)$ to $1773 \mathrm{~K}\left(1500{ }^{\circ} \mathrm{C}\right)$ proceeded to gaseous $\mathrm{SiO}$. The initial rate of reduction increased with increasing temperature, fluidization gas flow rate $(0.4-0.8 \mathrm{NL} / \mathrm{min})$ and methane content in the reducing gas (below 5 vol pct). However, temperature above 1723 $\mathrm{K}\left(1450{ }^{\circ} \mathrm{C}\right)$ and methane content above 5 vol pct caused significant methane cracking and carbon deposition on the surface of quartz particles, which hindered further reduction. In the 
1 reduction of quartz spheres at $1673 \mathrm{~K}\left(1400^{\circ} \mathrm{C}\right)$ to $1773 \mathrm{~K}\left(1500^{\circ} \mathrm{C}\right)$, a small amount of $\mathrm{SiC}$

2 was observed in the form of particles $\left(1673 \mathrm{~K}\left(1400^{\circ} \mathrm{C}\right)\right.$ and $\left.1723 \mathrm{~K}\left(1450{ }^{\circ} \mathrm{C}\right)\right)$ or whiskers

$3 \quad\left(1773 \mathrm{~K}\left(1500^{\circ} \mathrm{C}\right)\right)$.

\section{Acknowledgements}

5 This research was supported under the Australian Research Council Linkage Projects funding

6 scheme (Project No. LP100100866). Commonwealth Scientific and Industrial Research

7 Organization (CSIRO) provided quartz lumps crushing and grinding service. The electron

8 microscopy characterization was carried out at the Electron Microscopy Centre (EMC) at the

$9 \quad$ University of Wollongong.

\section{References}

1. A. Schei, J. Tuset, and H. Tveit: Production of High Silicon Alloys, Tapir Forlag, Trondheim, 1998.

2. S. Ranjan, S. Balaji, R.A. Panella, and B.E. Ydstie: Comput. Chem. Eng., 2011, vol. 35 (8), pp. 1439-53.

3. D.H. Filsinger and D.B. Bourrie: J. Am. Ceram. Soc., 1990, vol. 73 (6), pp. 1726-32.

4. J.G. Lee, P.D. Miller, and I.B. Cutler: Reactivity of solids, Plenum Press, New York, 1976.

5. N.S. Jacobson, K.N. Lee, and D.S. Fox: J. Am. Ceram. Soc., 1992, vol. 75 (6), pp. $1603-$ 11.

6. F. Aratani, Y. Sakaguchi, N. Yuge, M. Ishizaki, and T. Kawahara: Bull. Jpn. I. Met., 1991, 
vol. $30(5)$, pp. 433-5.

2 7. E.H. Myrhaug and H. Tveit: 58th Electric Furnace Conference and 17th Process 3 Technology Conference Proceedings, Warrendale, 2000, pp. 591-604.

4 8. U. Setiowati and S. Kimura: J. Am. Ceram. Soc., 1997, vol. 80 (3), pp. 757-60.

5 9. H.J. Choi and J.G. Lee: J. Mater. Sci., 1995, vol. 30 (8), pp. 1982-6.

6 10. J.V. Milewski, F.D. Gac, J.J. Petrovic, and S.R. Skaggs: J. Mater. Sci., 1985, vol. 20 (4), $7 \quad$ pp. $1160-6$.

8

11. G. Urretavizcaya and J.M.P. Lopez: J. Mater. Res., 1994, vol. 9 (11), pp. 2981-6.

12. X. Li, G. Zhang, R. Tronstad and O. Ostrovski: Ceram. Int., 2016, vol. 42(5), pp. 566876.

13. O. Ostrovski and G. Zhang: AIChE J., 2006, vol. 52 (1), pp. 300-10.

14. T.C. Glayton: Multiphase Flow Handbook, CRC Press, Boca Raton, 2008.

15. A.C.D. Chaklader and A.L. Roberts: J. Am. Ceram. Soc., 1961, vol. 44 (1), pp. 35-41.

16. G. Zhang and O. Ostrovski: Metall. Mater. Trans. B, 2000, vol. 31 (1), pp. 129-39.

17. X. Li, G. Zhang, K. Tang, O. Ostrovski and R. Tronstad: Metall. Mater. Trans. B, 2015, vol. 46 (5) 2384-93.

18. R.A. Gardner: J. Solid. State. Chem., 1974, vol. 9 (4), pp. 336-44.

19. G. Han and H.Y. Sohn: J. Am. Ceram. Soc., 2005, vol. 88 (4), pp. 882-8.

20. J. Szekely, J.W. Evans, and H.Y. Sohn: Gas-solid Reactions, Academic Press, New York, 1976. 
3 Table I. Impurity contents in the quartz lumps, $\mathrm{mg} / \mathrm{kg}$

4 Table II. Parameters of fluidization of quartz with different particle size ranges using pure

5 nitrogen

6 Table III. Parameters of fluidization of $100-140 \mu \mathrm{m}$ quartz particles by pure hydrogen at

7 different temperatures

8 Table IV. Experimental conditions and extent of reduction of $\mathrm{SiO}_{2}$ by $\mathrm{CH}_{4}-\mathrm{H}_{2}$ gas mixture $9 \quad$ after reaction for $120 \mathrm{~min}$

\section{Figure Captions}

Fig. 1-Schematic of the fluidized bed reactor setup.

Fig. 2-Effect of temperature on the evolution of $\mathrm{CO}$ in the reduction of quartz by $\mathrm{CH}_{4}-\mathrm{H}_{2}$ gas mixture $\left(5\right.$ vol pet $\left.\mathrm{CH}_{4}\right)$ at gas flow rate $0.8 \mathrm{NL} / \mathrm{min}$.

Fig. 3-XRD patterns of the samples reduced by $\mathrm{CH}_{4}-\mathrm{H}_{2}$ gas mixture (5 vol pct $\mathrm{CH}_{4}$ ) at different temperatures after 120 min reaction.

Fig. 4-Effect of gas flow rate on the reduction of quartz by $\mathrm{CH}_{4}-\mathrm{H}_{2}$ gas mixture (5 vol pct $\left.\mathrm{CH}_{4}\right)$ at $1723 \mathrm{~K}\left(1450{ }^{\circ} \mathrm{C}\right)$.

Fig. 5-Effect of methane content on the reduction of quartz by $\mathrm{CH}_{4}-\mathrm{H}_{2}$ gas mixture with flow rate $0.8 \mathrm{NL} / \mathrm{min}$ at $1723 \mathrm{~K}\left(1450{ }^{\circ} \mathrm{C}\right)$.

Fig. 6-Arrhenius plot calculated from peak rate of reduction at different temperatures.

Fig. 7- $\mathrm{CO}$ concentration in the off gas in the reduction of quartz sphere by the $\mathrm{CH}_{4}-\mathrm{H}_{2}$ gas mixture with 0.5 vol pet $\mathrm{CH}_{4}$ at different temperatures. The gas flow rate was $1.6 \mathrm{NL} / \mathrm{min}$. 
1 Fig. 8-SEM images of quartz spheres after reduction by the $\mathrm{CH}_{4}-\mathrm{H}_{2}$ gas mixture with 0.5 vol

2 pct $\mathrm{CH}_{4}$ at: (a) $1723 \mathrm{~K}\left(1450^{\circ} \mathrm{C}\right)$; (b) $1773 \mathrm{~K}\left(1500^{\circ} \mathrm{C}\right)$.

3 Fig. 9-SEM images of the surface of quartz sphere after reduction by the $\mathrm{CH}_{4}-\mathrm{H}_{2}$ gas 4 mixture with 0.5 vol pct $\mathrm{CH}_{4}$ at: (a) $1623 \mathrm{~K}\left(1350{ }^{\circ} \mathrm{C}\right)$; (b) $1673 \mathrm{~K}\left(1400{ }^{\circ} \mathrm{C}\right)$; (c) $1723 \mathrm{~K}$ $5 \quad\left(1450{ }^{\circ} \mathrm{C}\right) ;(\mathrm{d}) 1773 \mathrm{~K}\left(1500^{\circ} \mathrm{C}\right)$.

6

7

8

9

10

11

12

13 
1 Table I. Impurity contents in the quartz lumps, $\mathrm{mg} / \mathrm{kg}$

2

\begin{tabular}{cccccccc}
\hline $\mathrm{B}$ & $\mathrm{P}$ & $\mathrm{Fe}$ & $\mathrm{Al}$ & $\mathrm{Ca}$ & $\mathrm{Ti}$ & $\mathrm{Mn}$ & $\mathrm{Mg}$ \\
\hline 0.5 & 1.0 & 33.0 & 219.0 & 26.0 & 7.9 & 1.9 & 27.0 \\
\hline
\end{tabular}

3

4

5

6

7

8

9

10

11

12

13

14

15

16

17

18

19

20 
1 Table II. Parameters of fluidization of quartz with different particle size ranges using pure 2 nitrogen

\begin{tabular}{|c|c|c|c|c|}
\hline $\begin{array}{l}\text { Particle size } \\
\qquad(\mu \mathrm{m})\end{array}$ & $\begin{array}{l}\text { Calculated } U_{\mathrm{mf}} \\
\qquad(\mathrm{m} / \mathrm{s})\end{array}$ & $\begin{array}{c}\text { Calculated } U_{t} \\
\qquad(\mathrm{~m} / \mathrm{s})\end{array}$ & $\begin{array}{l}\text { Measured gas flow rate } \\
\text { at } \mathrm{U}_{\mathrm{mf}}(\mathrm{NL} / \mathrm{min})\end{array}$ & $\begin{array}{c}\text { Measured } U_{\mathrm{mf}} \\
(\mathrm{m} / \mathrm{s})\end{array}$ \\
\hline $53-100$ & 0.0090 & 0.239 & $\begin{array}{c}\text { Fluidization was not } \\
\text { observed; }\end{array}$ & N/A \\
\hline $100-140$ & 0.0180 & 0.956 & 0.32 & 0.0170 \\
\hline $140-200$ & 0.0361 & 1.667 & 0.41 & 0.0220 \\
\hline
\end{tabular}

3

4

5

6

7

8

9

10

11

12

13

14

15 
1 Table III. Parameters of fluidization of 100-140 $\mu \mathrm{m}$ quartz particles by pure hydrogen at 2 different temperatures

\begin{tabular}{ccccc}
\hline Temperature & Calculated & Calculated gas flow & Calculated $\mathrm{U}_{\mathrm{t}}$ & Calculated gas flow \\
& $\mathrm{U}_{\mathrm{mf}}(\mathrm{m} / \mathrm{s})$ & rate at $\mathrm{U}_{\mathrm{mf}}(\mathrm{NL} / \mathrm{min})$ & $(\mathrm{m} / \mathrm{s})$ & rate at $\mathrm{U}_{\mathrm{t}}(\mathrm{NL} / \mathrm{min})$ \\
\hline $1623 \mathrm{~K}\left(1350^{\circ} \mathrm{C}\right)$ & 0.0113 & 0.036 & 0.545 & 1.728 \\
$1673 \mathrm{~K}\left(1400^{\circ} \mathrm{C}\right)$ & 0.0111 & 0.034 & 0.534 & 1.644 \\
$1723 \mathrm{~K}\left(1450^{\circ} \mathrm{C}\right)$ & 0.0109 & 0.033 & 0.524 & 1.566 \\
$1773 \mathrm{~K}\left(1500^{\circ} \mathrm{C}\right)$ & 0.0107 & 0.031 & 0.515 & 1.494 \\
\hline
\end{tabular}

3

4

5

6

7

8

9

10

11

12

13

14

15 
1 Table IV. Experimental conditions and extent of reduction of $\mathrm{SiO}_{2}$ by $\mathrm{CH}_{4}-\mathrm{H}_{2}$ gas mixture

2 after reaction for $120 \mathrm{~min}$

\begin{tabular}{cccccc}
\hline Sample & Temperature & Fluidization flow & Methane content & Weight loss & Reduction Extent \\
& & rate $(\mathrm{NL} / \mathrm{min})$ & $($ vol pct $)$ & $(\mathrm{pct})$ & (pct) \\
\hline 1 & $1623 \mathrm{~K}\left(1350^{\circ} \mathrm{C}\right)$ & 0.8 & 5 & 7.8 & 4.4 \\
2 & $1673 \mathrm{~K}\left(1400^{\circ} \mathrm{C}\right)$ & 0.8 & 5 & 29.0 & 25.0 \\
3 & $1723 \mathrm{~K}\left(1450^{\circ} \mathrm{C}\right)$ & 0.8 & 5 & 38.1 & 32.0 \\
4 & $1723 \mathrm{~K}\left(1450^{\circ} \mathrm{C}\right)$ & 0.4 & 5 & 20.0 & 18.2 \\
5 & $1723 \mathrm{~K}\left(1450^{\circ} \mathrm{C}\right)$ & 0.6 & 5 & 28.4 & 24.8 \\
6 & $1723 \mathrm{~K}\left(1450^{\circ} \mathrm{C}\right)$ & 0.8 & 2 & 21.9 & 18.6 \\
7 & $1723 \mathrm{~K}\left(1450^{\circ} \mathrm{C}\right)$ & 0.8 & 10 & 8.3 & 26.2 \\
\hline 8 & $1773 \mathrm{~K}\left(1500^{\circ} \mathrm{C}\right)$ & 0.8 & 5 & 31.2 & \\
\hline
\end{tabular}

3

4

5

6

7

8

9

10 


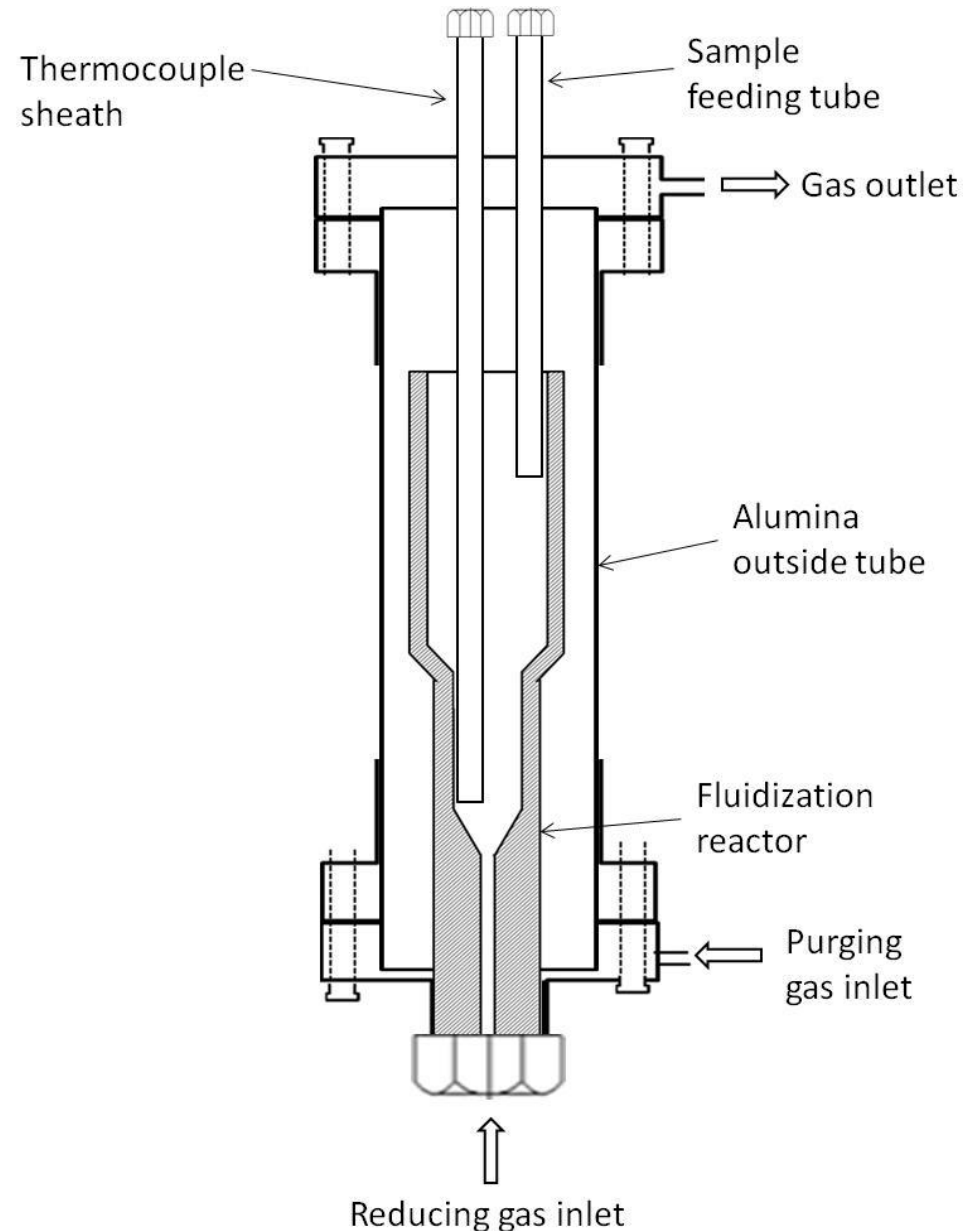

2 Fig. 1-Schematic of the fluidized bed reactor setup.

3

4

5

6

7

8

9

10

11 


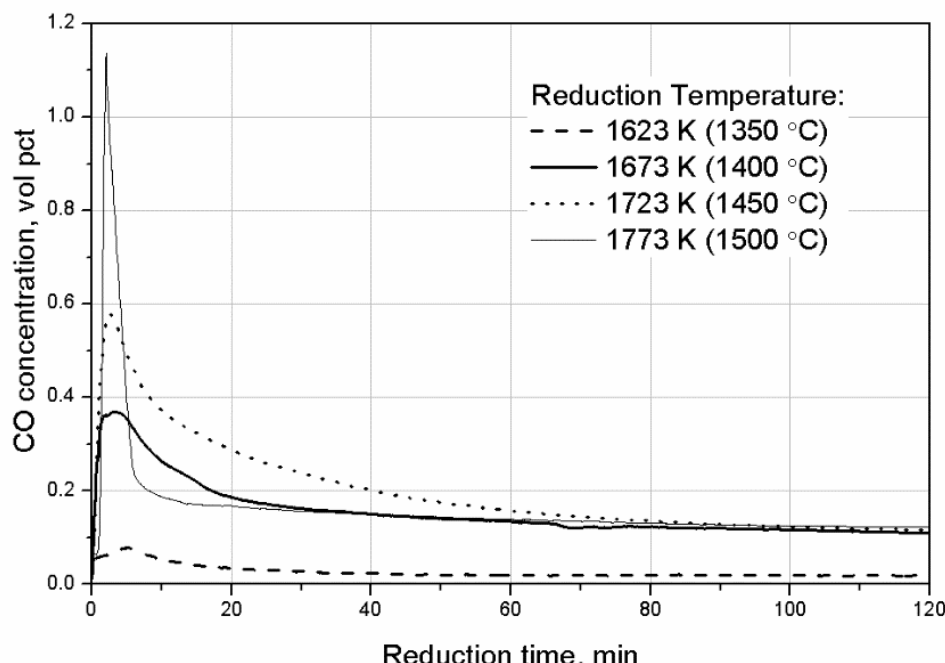

1

2 Fig. 2-Effect of temperature on the evolution of $\mathrm{CO}$ in the reduction of quartz by $\mathrm{CH}_{4}-\mathrm{H}_{2}$ gas

3 mixture $\left(5 \mathrm{vol} \mathrm{pet} \mathrm{CH}_{4}\right)$ at gas flow rate $0.8 \mathrm{NL} / \mathrm{min}$.

4

5

6

7

8

9

10

11

12

13

14

15

16

17 


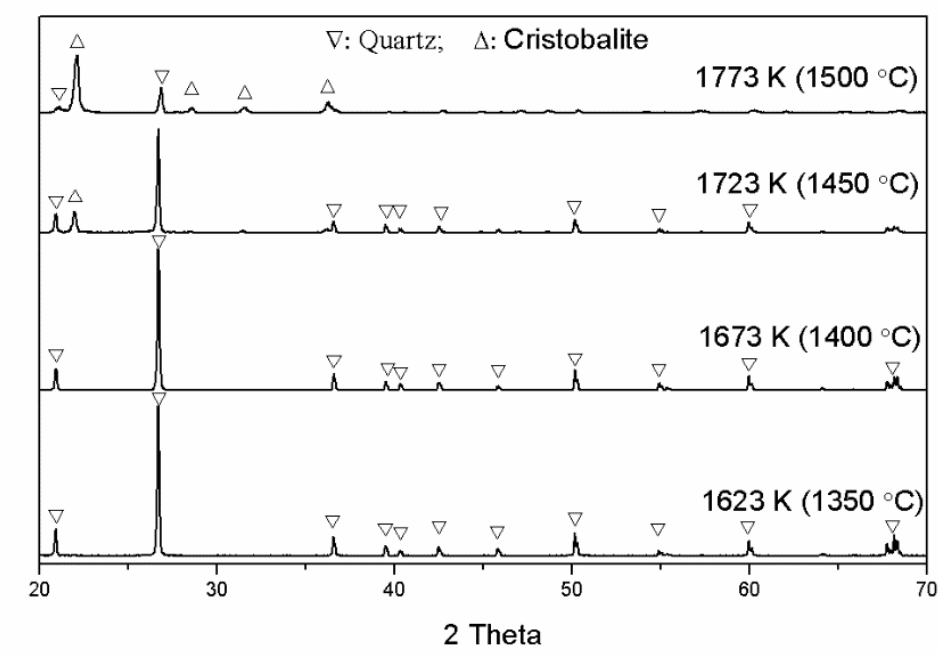

1

2 Fig. 3-XRD patterns of the samples reduced by $\mathrm{CH}_{4}-\mathrm{H}_{2}$ gas mixture $\left(5\right.$ vol pet $\left.\mathrm{CH}_{4}\right)$ at 3 different temperatures after 120 min reaction.

4

5

6

7

8

9

10

11

12

13

14

15

16

17 


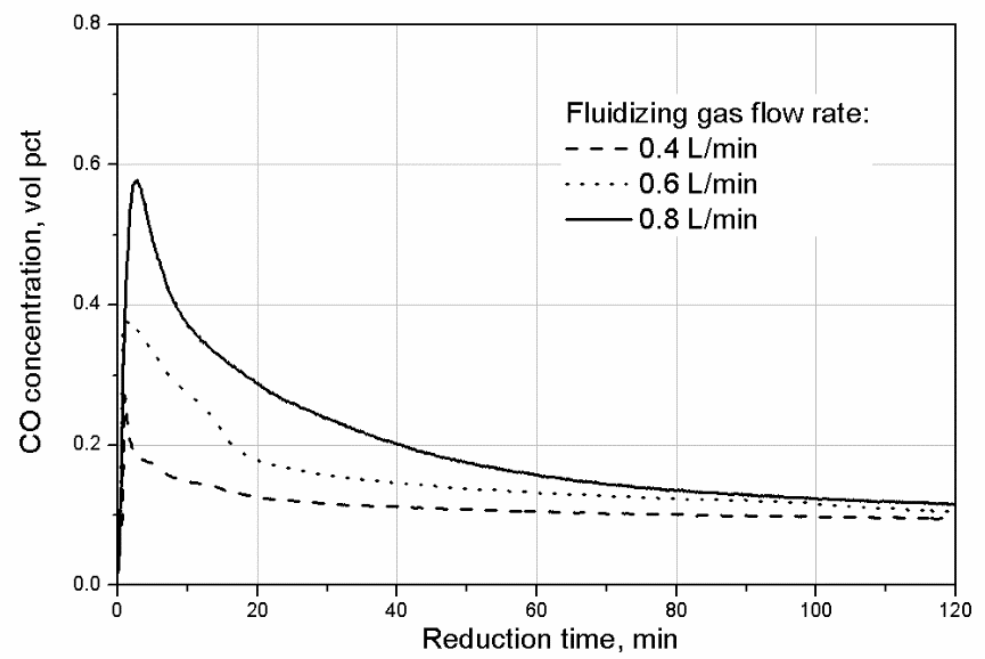

2 Fig. 4-Effect of gas flow rate on the reduction of quartz by $\mathrm{CH}_{4}-\mathrm{H}_{2}$ gas mixture (5 vol pct

$\left.3 \quad \mathrm{CH}_{4}\right)$ at $1723 \mathrm{~K}\left(1450{ }^{\circ} \mathrm{C}\right)$.

4

5

6

7

8

9

10

11

12

13

14

15

16

17 


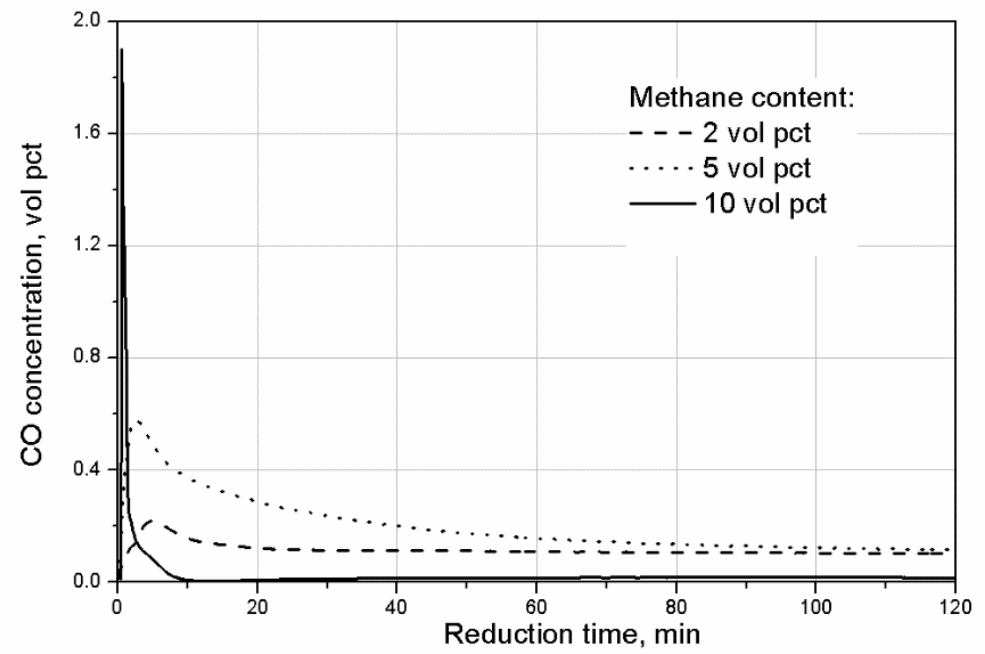

2 Fig. 5-Effect of methane content on the reduction of quartz by $\mathrm{CH}_{4}-\mathrm{H}_{2}$ gas mixture with flow

3 rate $0.8 \mathrm{NL} / \mathrm{min}$ at $1723 \mathrm{~K}\left(1450{ }^{\circ} \mathrm{C}\right)$.

4

5

6

7

8

9

10

11

12

13

14

15

16

17 


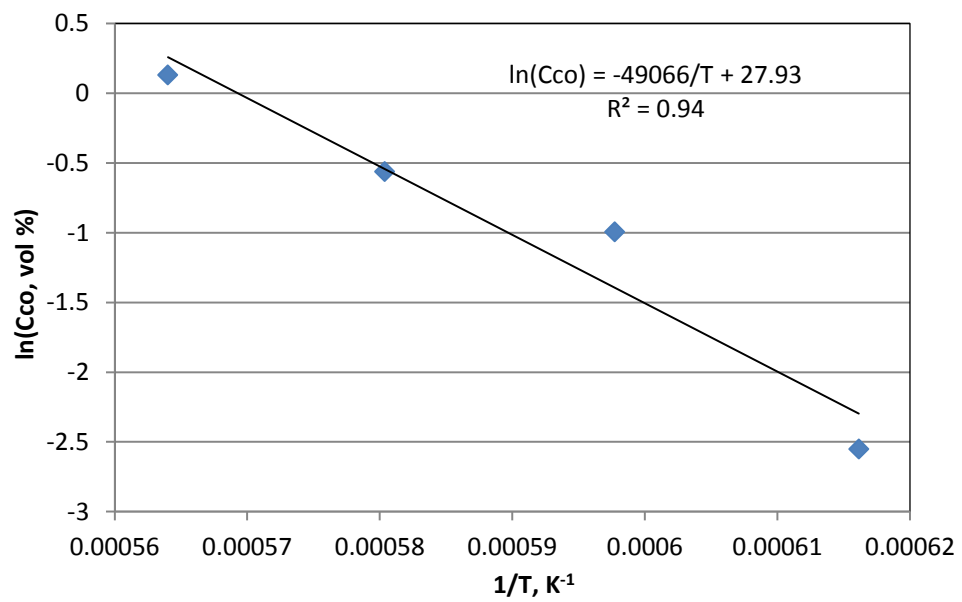

2 Fig. 6-Arrhenius plot calculated from peak rate of reduction at different temperatures.

3

4

5

6

7

8

9

10

11

12

13

14

15

16

17 


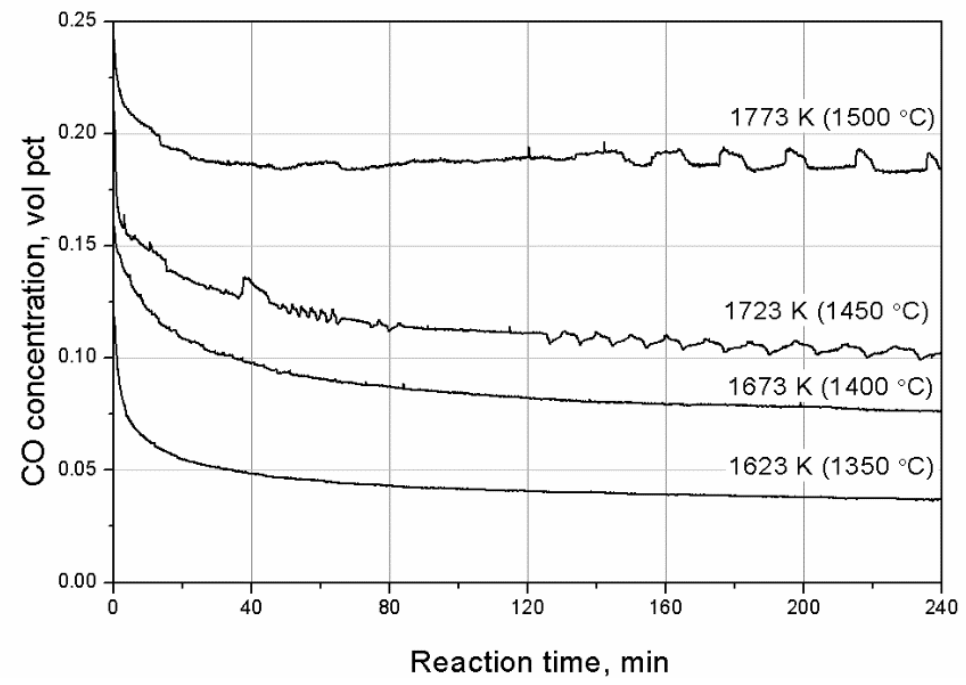

1

2 Fig. 7-CO concentration in the off gas in the reduction of quartz sphere by the $\mathrm{CH}_{4}-\mathrm{H}_{2}$ gas

3 mixture with 0.5 vol pet $\mathrm{CH}_{4}$ at different temperatures. The gas flow rate was $1.6 \mathrm{NL} / \mathrm{min}$.

4

5

6

7

8

9

10

11

12

13

14

15

16

17 
$\mathbf{a}$

SEI PC-std. $15 \mathrm{KV} \times 50$

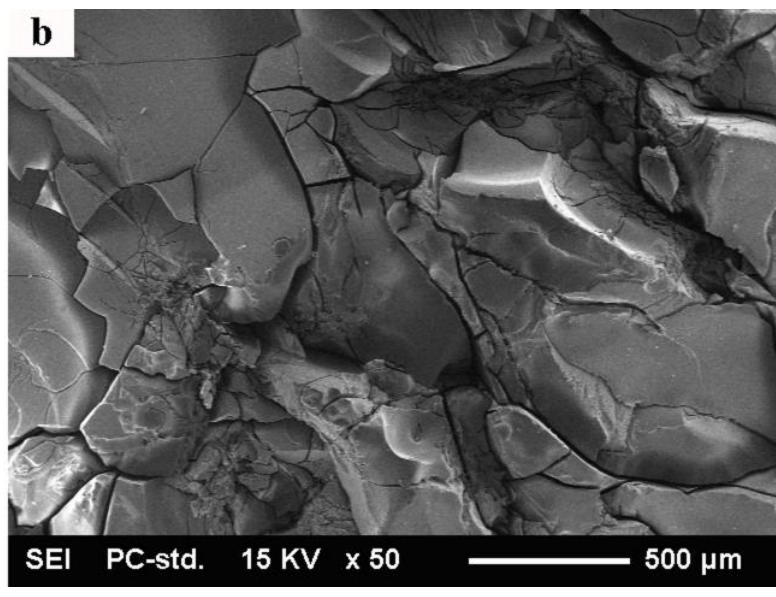

$500 \mu \mathrm{m}$

SEI PC-std. $15 \mathrm{KV} \times 50$

$500 \mu \mathrm{m}$

2 Fig. 8-SEM images of quartz spheres after reduction by the $\mathrm{CH}_{4}-\mathrm{H}_{2}$ gas mixture with 0.5 vol

3 pet $\mathrm{CH}_{4}$ at: (a) $1723 \mathrm{~K}\left(1450^{\circ} \mathrm{C}\right)$; (b) $1773 \mathrm{~K}\left(1500{ }^{\circ} \mathrm{C}\right)$.

4

5

6

7

8

9

10

11

12

13

14 

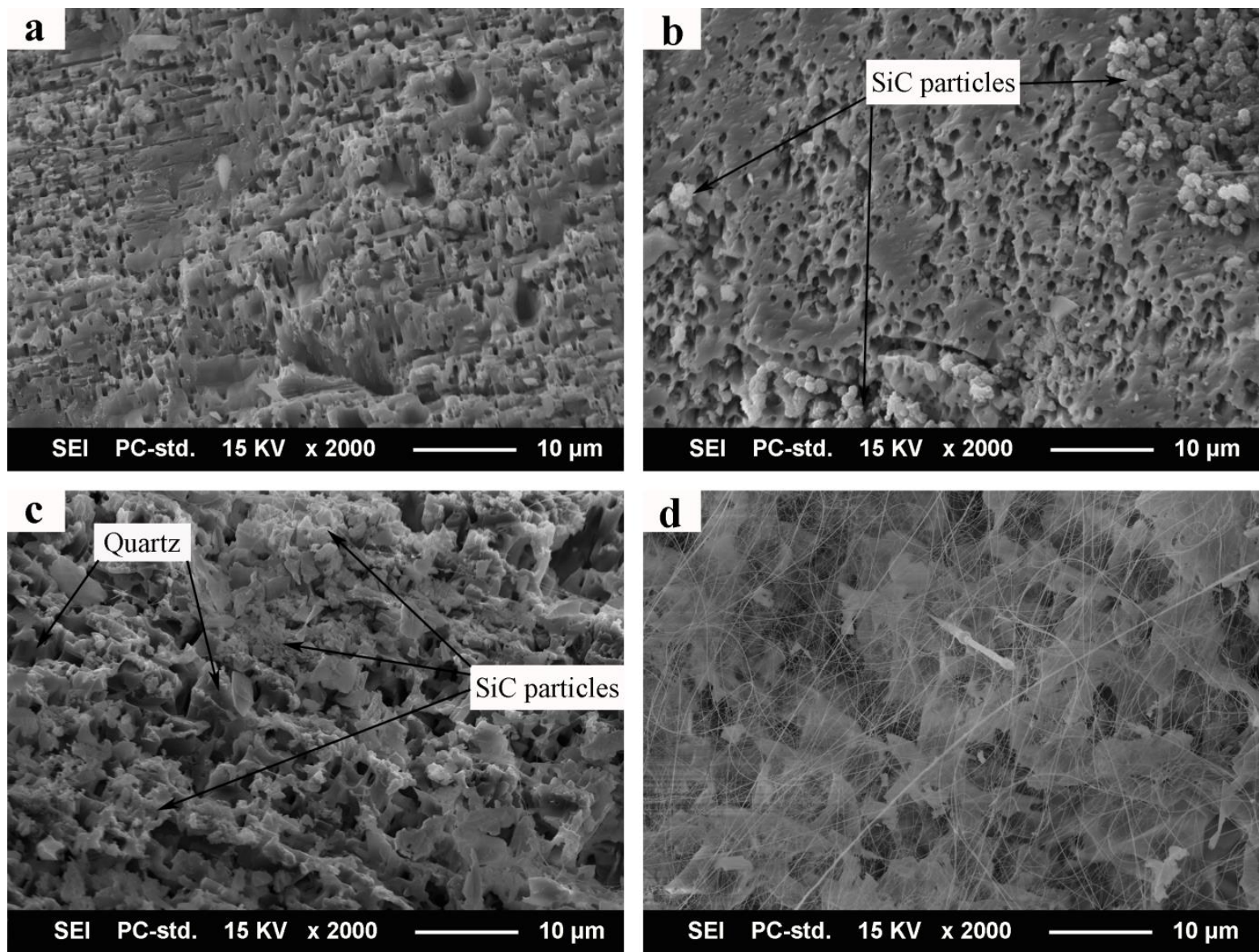

2 Fig. 9-SEM images of the surface of quartz sphere after reduction by the $\mathrm{CH}_{4}-\mathrm{H}_{2}$ gas

3 mixture with 0.5 vol pct $\mathrm{CH}_{4}$ at: (a) $1623 \mathrm{~K}\left(1350{ }^{\circ} \mathrm{C}\right)$; (b) $1673 \mathrm{~K}\left(1400{ }^{\circ} \mathrm{C}\right)$; (c) $1723 \mathrm{~K}$

$4 \quad\left(1450{ }^{\circ} \mathrm{C}\right) ;(\mathrm{d}) 1773 \mathrm{~K}\left(1500^{\circ} \mathrm{C}\right)$. 